\title{
Characterization of Past Seasonal Climate Variability in Oromia Special Zone, North Eastern Ethiopia
}

\author{
Yimer Mohammed $^{1}$ Dr.Gashaw Bimrewu ${ }^{2}$ Dr. Lisanwork Nigatu ${ }^{3}$ \\ 1.East Amhara Meteorolgy Service Center, Kombolcha, Ethiopia, P.O. Box 94 \\ 2.School of College of Agriculture and Environmental Sciences, BahrDar University, BahrDar, Ethiopia \\ 3.School of Natural Resource Mang \& Environmental Sciences ,Haramaya University. P.O.Box 138, Dire Dawa, \\ Ethiopia
}

\begin{abstract}
This study was undertaken in oromia special zone of Amhara National Regional State to analyze past climate variability. Gridded climate data were obtained from National Meteorology Agency of Ethiopia. Standard stastical descriptors and statistical software like Instat V3.37, MAKESENS, XLSTAT 2014 and Arc GIS 10.1 were employed for the analysis and interpretation for results. The results indicated that the OSZ experienced moderate rainfall variability in kiremt (JJAS) season and very high variability in belg (FMAM) season . Increasing trend in kiremt rainfall while decreasing trend in belg rainfall. Except belg minimum temperature, also temperature trend increased. The median of the start of belg season did not between March and May. The risk of getting 5,7,10 and 15 days of dry spells based on the fitted first order Markov chain probability values indicate in belg season the probability of dry spell occurrence of 10 days' length was $60 \%$. In kiremt season, the dry spell risk of being greater than 10 day consecutive dry spells was less than $50 \%$, and it is expected to occurred beteewen 178 DOY (June 26) to 262 DOY (Sept 18). District level of upcoming season climate information in terms of climate variability and encourage farmers to benefit from these services, apply adaptation and mitigation strategy are important for reduce the challenges of cropping practices in the study area.
\end{abstract}

Keywords:- Belg, Kiremt, Oromia, special Variavility

DOI: $10.7176 / \mathrm{JBAH} / 10-1-06$

Publication date: January $31^{\text {st }} 2020$

\section{INTRODUCTION}

Ethiopia's climate is prone to both extended rainfall deficits and excesses (Korecha, 2013). Studies in Ethiopia have shown that the causes for rainfall variability are erratic nature of rainfall distribution and late onset and early offset contribute to decline in crop yields with reasonable amount in almost all parts of the country (Godswill et al., 2007). Assessing the characteristics of temperature and rainfall for a location is useful for choosing the most appropriate enterprises, and the most productive plant cultivars (Mavi and Tupper, 2004). In recent years, a case study made in parts of Ethiopia examined the impact of rainfall variability on the Ethiopia economy, and found that rainfall variability in the country led to a production deficit of $20 \%$, and increase in poverty rates by $25 \%$ which costed by the economy over one-third of its growth potential (Hagos et al., 2009). There are only a few studies on the effects of climate variability on crop production in Ethiopia (Bewket, 2009) either at national or regional scales which mask local scale variability like Oromia special zone.

Having knowledge on sequences of rainfall variability, events can assist acquiring specific information for agricultural planning (Mandal et al., 2013). Within variable seasonal rainfall patterns, understanding the events of the occurrence of rain features like; onset and end date of rainy season, dry spells are crucial to decrease the adverse effects and exploit opportunities (Yemenu and Chemeda, 2013).The study of past inter seasonal rainfall variability in terms of onset, end date and length of rainy season, number of rainy days, length of dry spell within the growing period and its trend is important for agricultural purposes in the dry land area than annual and seasonal totals (Hadgu et al., 2013).

Rainfall during a year occurs in different seasons, three seasons are known in Ethiopia, namely bega, belg and kiremt (NMA, 2007). So the main objective of this paper is to anylas two rainy season climate varavility of the special zone.

\section{MATERIALS AND METHODS}

\subsection{DESCRIPTION OF THE STUDY AREA}

The study area covers Oromia Special Zone found in North Eastern of Ethiopia. Geographically, it is located between $10^{\circ} 00^{\prime} \mathrm{N}$ to $11^{\circ} 30^{\prime} \mathrm{N}$ latitude and $39^{\circ} 40^{\prime} \mathrm{E}$ to $40^{\circ} 20^{\prime} \mathrm{E}$ longitude (Figure 1). Kemisse is the administrative center of the Zone which is located at $326 \mathrm{~km}$ north east of Addis Ababa, the capital city of Ethiopia. 


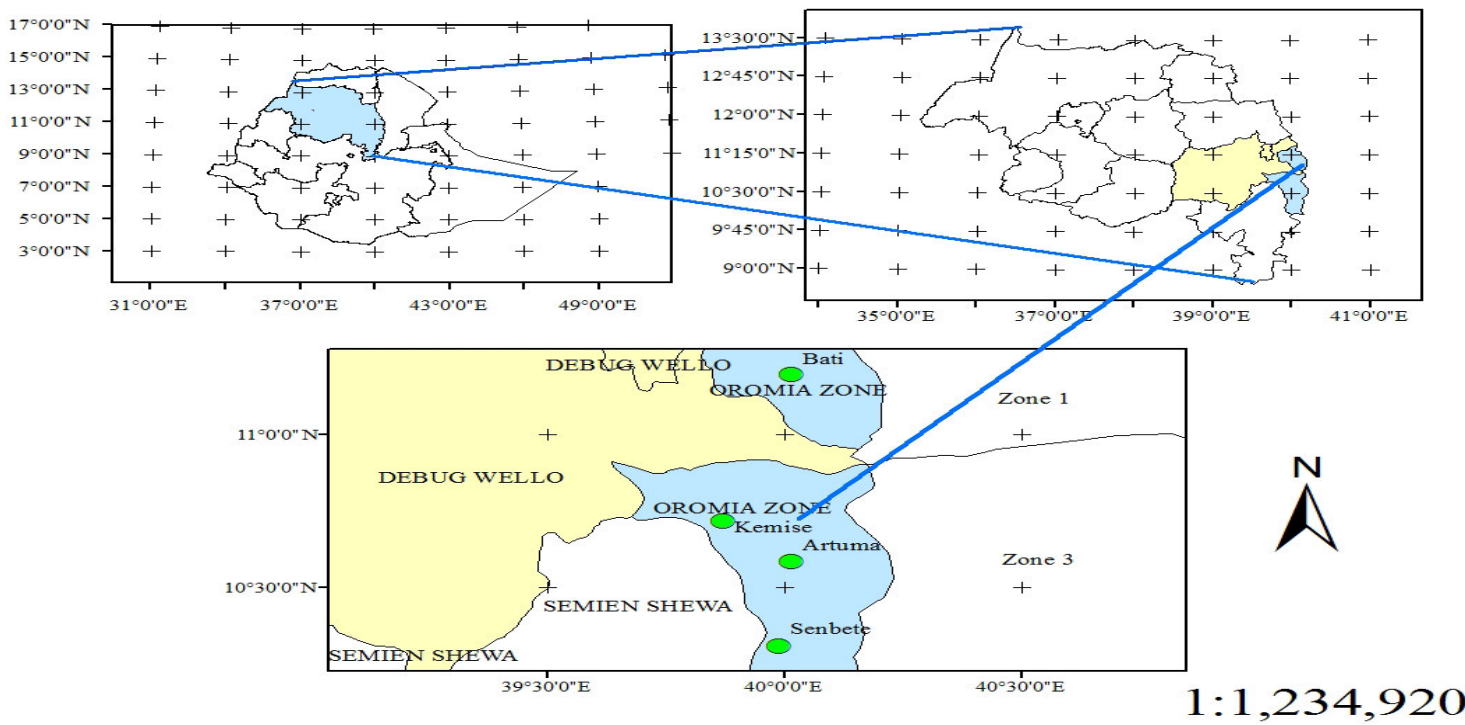

Figure 1. Map of the study area with selected stations

\subsection{DATA COLLECTION}

The choice of the four districts were based on representativeness of geographical settings in the study area (fig1). The Special Zone has lack of long year observed climate data. As a result, gridded daily rainfall and dekedal temperature data of four weather station points for the time period 1986 to 2015 were collected from National Meteorology Agency of Ethiopia used for these analyses.

\subsection{DATA ANALYSIS}

\subsubsection{VARIABILITY ANALYSIS USING STATISTICAL PARAMETERS}

Analysis of two rainy season rainfall and temperature and involved characterizing long-term mean values, and calculation of indices of variability, and trends at seasonal and annual time scales.

Heterogeneity of monthly rainfall amount were investigated using the precipitation Concentration Index (PCI). The seasonal PCI values were calculated as given by Oliver (1980) as follows:

$\mathrm{PCI}$ on seasonal scale calculated as:

$$
P C I \quad=\frac{100}{3} * \frac{\sum_{i=1}^{4} p_{i}^{2}}{\sum_{i=1}^{4}\left(p_{i}\right)^{2}}
$$

Where, Pi is the rainfall amount of the $\mathrm{i}^{\text {th }}$ month; and $\Sigma=$ summation over the 12 months incase of annual time scale and four months incase of seasonal time scale.

According to this classification, Oliver (1980) suggested that PCI values less than 10 represents a uniform precipitation distribution (i.e., low precipitation concentration); PCI values from 11 to 15 denote a moderate precipitation concentration; values from 16 to 20 denote irregular distribution, and values above 20 represent a strong irregularity (i.e., high precipitation concentration) of precipitation distribution.

Coefficient of variation, standard deviation, and mean were used to analyze the variation in explanatory variables (rainfall characteristics and temperature).

Scientifically, using the following formula.

$C V \quad=\frac{S D}{X} * 100$

Where, $\mathrm{CV}$ is coefficient of variation, $\mathrm{SD}$ is the standard deviation and $\overline{\mathrm{x}}$ mean of observed data. According to

Hare (1983), CV (\%) values are classified as follows: $<20 \%$ as less variable, $20-30 \%$ as moderately variable, and $>30 \%$ as highly variable.

Standard deviation was calculated from the observed data, mean and number of the observations as follows:

$S D$

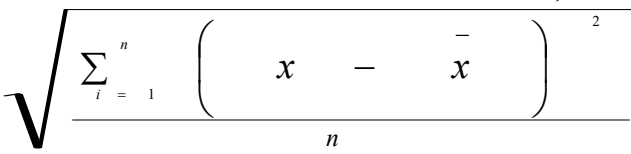

Where, $\mathrm{SD}$ is the standard deviation, $\mathrm{x}$ is an observed value, $\overline{\mathrm{x}}$ is mean of observation data and $\mathrm{n}$ is number of observations (years). Using the classification of Reddy (1990), the stability of rainfall is examined as follows: 
when standard deviation $<10$ as very high stabilities, 10-20 as high stability, and 20-40 as moderate stability and $>40$ as less stability. In addition standard statistical tool and software like instat V3.37, XLSTAT 2014 and Microsoft Excel 2016 were used for the purpose of anyalysis.

\subsubsection{SEASONAL RAINFALL ANOMALY}

As described by Agnew and Chappel (1999) the standardized rainfall anomaly (Zij) were used to characterize the annual and seasonal drought frequency and intensity, and inter seasonal fluctuations of rainfall and crop yield as given below.

$$
Z \quad Z_{i j}=\frac{x-\bar{x}}{S D}
$$

Where, $Z_{\mathrm{ij}}$ is normalized rainfall total for station $\mathrm{i}$ during a year (or season) $\mathrm{j} ; \mathrm{X}$ is an observed annual and seasonal rainfall value, $\overline{\mathrm{x}}$ is mean and $\mathrm{SD}$ is the standard deviation. This statistic enables us to determine the dry

(-ve values) and wet (+ve values) years in the records. The drought severity classes are extreme drought $\left(Z_{\mathrm{ij}}<-\right.$ $1.65)$, severe drought $\left(-1.28>Z_{\mathrm{ij}}>-1.65\right)$, moderate drought $\left(-0.84>\mathrm{Z}_{\mathrm{ij}}>-1.28\right)$, and no drought $(\mathrm{Zij}>-0.84)$ (Agnew and Chappel, 1999).

\subsubsection{TREND ANALYSES}

In this study, non-parametric Mann-Kendall's trend test were used for the assessment of past and future climate trend at annual and seasonal time scales. Mann-Kendall's trend test which is less sensitive to outliers and test for a trend in a time series without specifying whether the trend is linear or non-linear

The Mann-Kendall's test statistic was given as:

$$
S=\sum_{i=1}^{N} \sum_{J=i+1}^{N} \operatorname{Sgn}\left(X_{j}-X_{i}\right)
$$

Where, $S$ was the Mann-Kendal's test statistics; $X_{i}$ and $X_{j}$ were the sequential data values of the time series in the years $i$ and $j(j>i)$ and $N$ was the length of the time series. A positive $S$ value indicates an increasing trend and a negative value indicates a decreasing trend in the data series.

The sign function was computed as:

$$
\operatorname{Sgn}\left(X_{J}-X_{i}\right)=\left\{\begin{array}{l}
+1 \text { if }\left(X_{j}-X_{i}\right)>0 \\
0 \text { if }\left(X_{j}-X_{i}\right)=0 \\
-1 \text { if }\left(X_{j}-X_{i}<0\right.
\end{array}\right\}
$$

The variance of $\mathrm{S}$, for the situation where there may be ties (that is, equal values) in the $\mathrm{x}$ values is given by:

$$
\operatorname{Var}(S)=\frac{1}{18}\left[N(N-1)(2 N+5)-\sum_{i=1}^{m} t_{i}\left(t_{i}-1\right)\left(2 t_{i}+5\right)\right]
$$

Where, $m$ was the number of tied groups in the data set and $t_{i}$ was the number of data points in the $i_{\text {th }}$ tied group. For $\mathrm{N}$ larger than 10, $\mathrm{Z}_{\mathrm{MK}}$ approximates the standard normal distribution (Yenigun et al., 2008) and computed as follows:

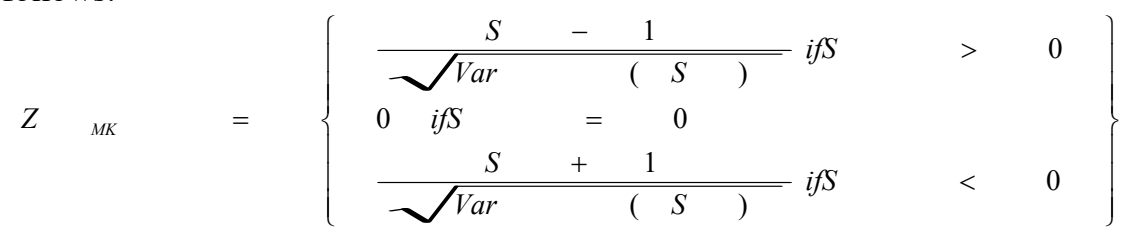

The presence of a statistically significant trend was evaluated using the $Z_{M K}$ value. In a two-sided test for trend, the null hypothesis Ho was accepted if $\left|Z_{M K}\right|<Z_{1-\alpha / 2}$ at a given level of significance. $Z_{1-\alpha / 2}$ was the critical value of $Z_{\mathrm{MK}}$ from the standard normal table. For example: for 5\% significance level, the value of $\mathbf{Z}_{\mathbf{1}-\boldsymbol{\alpha} / \mathbf{2}}$ is 1.96 . A positive value of $Z_{M K}$ indicates an increasing trend while a negative value indicates a decreasing trend. In the present study, the significance of the observed change was examined at $p \leq 0.05,0.01$, and 0.001 significance

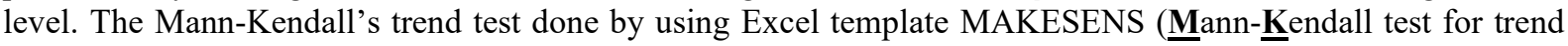
and Sen's slope estimates) 1.0.

To analyse spatial distribution of climatic elements were rasterized to generate grided point data by the simple kriging interpolation technique using ARCGIS 10.1 software. This is because simple kriging interpolation technique takes account of the spatial correlation pattern with the least interpolation error (Beck et al., 2005).

\subsection{DETERMINATION OF RAINFALL CHARACTERISTICS}

\subsubsection{START , END AND LENGTH OF THE GROWING SEASON}

In setting an onset date of the past records, many different criteria could be use for different crops exhibiting different maturity plus drought tolerance levels and soil types. Here, the one with $20 \mathrm{~mm}$ of total rainfall 
received over three consecutive days that were not followed by greater than 10 days of dry spell length within 30 days from planting was adopted (Raman, 1974).

On the other hand, the end of growing season is mainly dictated by the water stored in soil and its availability to the crop after the rain stops. In this study $100 \mathrm{~mm} / \mathrm{meter}$ of the plant available soil water and site specific daily reference evapotranspiration (ETo) values were considered, and the end of the growing season was taken defined as any day after $1^{\text {st }}$ of September for kiremt seasons when the soil water balance reaches zero (Stern et al., 1982).

In determining the end date, set an estimated evapotranspiration showed in table 1 and $100 \mathrm{~mm} / \mathrm{m}$ of the plant available soil water were considered. For the present study, Hargreaves and Samani (HS) method was applied to estimate ETo based on observed daily temperature data after calibration and validation of HS model against of FAO Penman Monteith cropwat 8.0 calibrated by Bati station. Estimat ETo at Bati, Kemisse, Artuma and take an average value for Senbete district.

Table 1. Estimated mean kiremt and belg season ETo in $\mathrm{mm}$ /day after calibration

\begin{tabular}{cccc|}
\hline Seasons/ Stations & Bati & Kemisse & Artuma \\
\hline Period & $1995-2015$ & $2004-2015$ & $2008-2015$ \\
Kiremt & 4.29 & 4.67 & 4.45 \\
Belg & 4.12 & 4.75 & 4.24 \\
\hline
\end{tabular}

The onset and cessation of rainfall date are analyzed using an Instat version 3.37 package developed by the Statistical Services Centre of the University of Reading (Stern et al., 2006).

Length of kiremt growing season (LGP) were determined as the difference between the end and start of rainy seasons. Mesay (2006), Hadgu et al. (2013) and Hadgu et al. (2014) used the same method to determined LGP.

\subsubsection{RAINFALL TOTALS AND NUMBER OF RAINY DAYS}

In the context of Ethiopia, Segele and Lamb (2005) employed three rainfall thresholds to define a rainy day $(0.1 \mathrm{~mm}, 0.5 \mathrm{~mm}$ and $1 \mathrm{~mm})$ but a threshold value of $1 \mathrm{~mm}$ were used to define days as wet or dry; because $<1 \mathrm{~mm}$ of rainfall value almost has no effect on growth of crops (Robel et al., 2013). Thus, in present study, number of rainy days were determined by counting all days with rainfall greater or equal to1.0 $\mathrm{mm}$ as outlined by (NMSA, 2001). Seasonal (for kiremt June to September and for belg February to end of May) rainfall totals were determined as sum of rainfall of each day with greater or equal to $1 \mathrm{~mm}$. Different researchers used the same methods (Segele and Lamb, 2005; Mesay, 2006; Hadgu et al., 2013; Muluneh, 2015).

\subsubsection{PROBABILITY OF DRY SPELL}

The dry spell probabilities were determined as consecutive number of days with rainfall less than $1 \mathrm{~mm}$ per day exceeding 5, 7, 10 and 15 consecutive days. Dry spell length was analyzed by first order Markov Chain analysis (Stern et al., 2006) using INSTAT v3.37 software.

\section{RESULT AND DISCUSSIONS}

\subsection{DISTRIBUTION OF SEASONAL RAIN FALL}

Figure 2. presents the monthly rainfall distribution of the study area. The highest rainfall was observed in the month of August across the Special Zone and the amount increased from Bati $(209.7 \mathrm{~mm})$ to Senbete $(312.2$ $\mathrm{mm})$. While in belg season the highest monthly rainfall was observed in the month March at Bati and April at Kemisse, Artuma and Senbete (figure 3). 

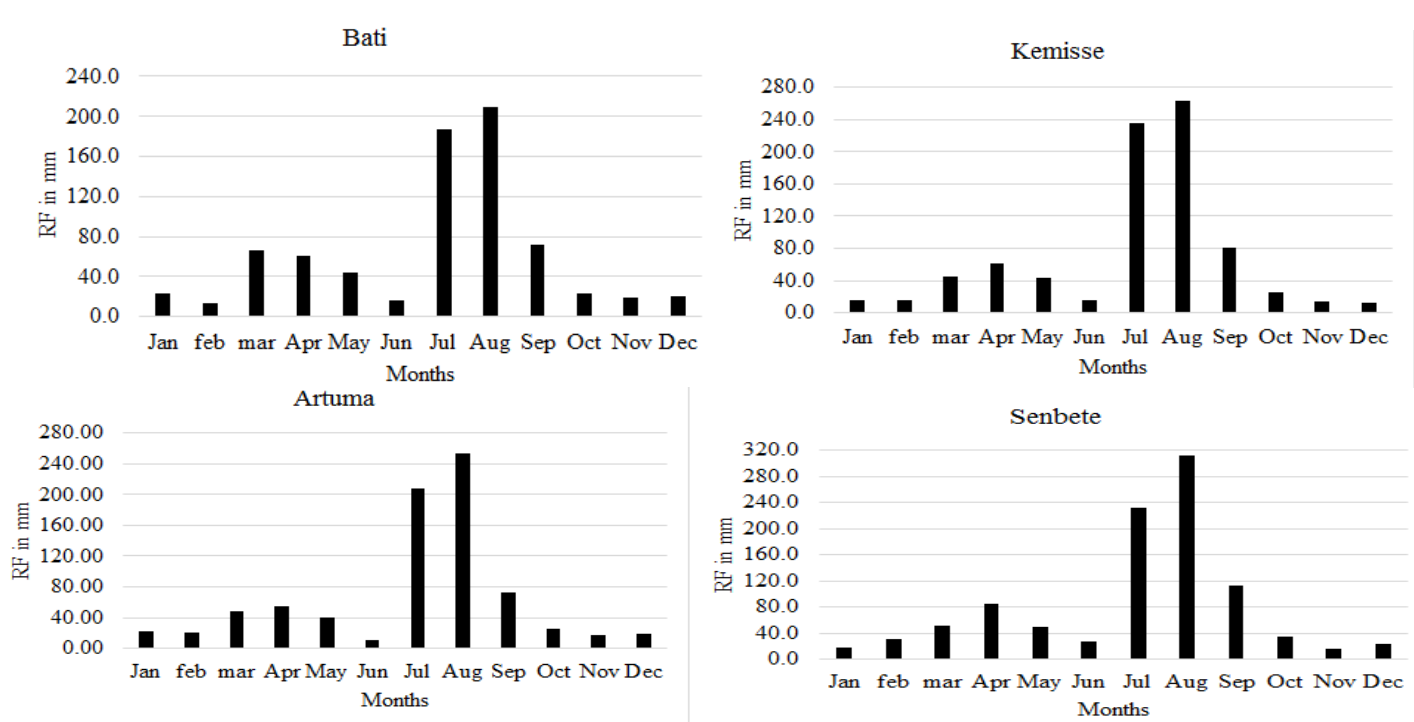

Figure 2. Mean monthly rainfall distribution at Oromia Special Zone, during 1986-2015
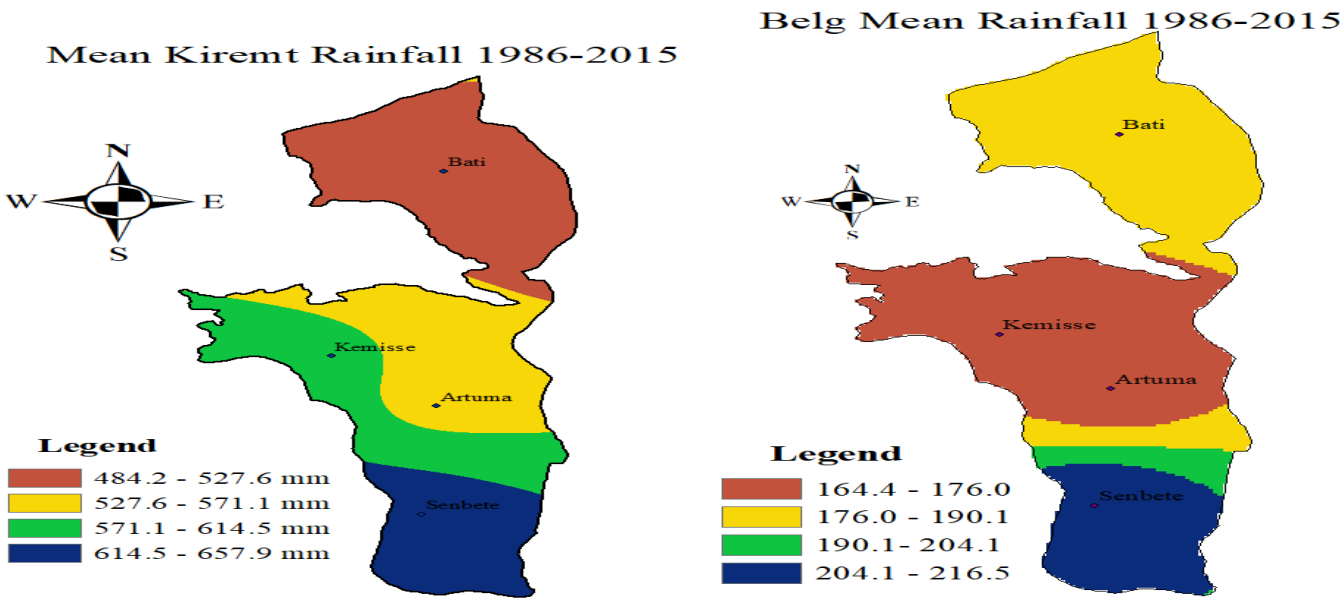

Figure 3. Spatial distripution maen seasonal rainfall 1986-2015.

Figure 3 shows that, in kiremt season lowest rainfall observed in northern part of the region (Bati) and highest rainfall recorded in southern part ( Senbete)of the Special zone. But in belg season lowest rainfall performed at centeral part (Kemisse and Artuma) and highest rainfall recoreds in the southern part (Senbete) of the special zone (figure 3 ).

\subsection{SEASONA RAINFALL VARIABILITY}

Kiremt season rainfall variability In all the study stations as revealed in Table 2, the main rainy season (kiremt) contributes the maximum to the annual rainfall with the highest contribution in Kemisse (71.8\%) and the lowest in Bati (64.2\%). Similar result was also reported by Muluneh (2015) with contribution of seasonal kiremt rainfall to annual total rainfall varied from $60 \%$ at Srinka to $76 \%$ at Lalibela in NEA during the period of 1992 2012.

The mean total kiremt season rainfall varied from $484.1 \mathrm{~mm}$ at Bati to $681.7 \mathrm{~mm}$ at Senbete of the Special Zone with CV ranged from $22.6 \%$ to $30.4 \%$ and SD ranged from $\pm 109.4 \mathrm{~mm}$ to $\pm 207.2 \mathrm{~mm}$, respectively (table 2). The result showed that, the Special Zone experienced moderate rainfall variability and less stability of rainfall kiremt season. This less stability showed that the kiremt rainfall totals were not easily predictable and could result in difficult decision regarding rain fed crop production during the study period. Similar results were also reported by Muluneh (2015), Hadgu et al. (2013) and Bewket (2009) in the north and north eastern parts of Ethiopia. The PCI of the kiremt season revealed values between 11 and 16, which that implies the Special Zone had moderate monthly rainfall distribution for the kiremt season (Table 2). 
Table 2. Past seasonal rainfall Variability at OSZ, during (1986-2015)

\begin{tabular}{|c|c|c|c|c|c|c|c|c|}
\hline \multirow{2}{*}{ 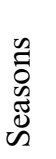 } & \multirow{2}{*}{ 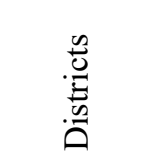 } & \multicolumn{7}{|c|}{ Statistics } \\
\hline & & $\operatorname{Min}(\mathrm{mm})$ & $\operatorname{Max}(\mathrm{mm})$ & Mean (mm) & $\mathrm{SD}(\mathrm{mm})$ & $\mathrm{CV} \%$ & $\mathrm{CT} \%$ & PCI \\
\hline \multirow{4}{*}{ 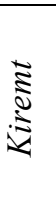 } & Bati & 301.0 & 728.0 & 484.1 & 109.4 & 22.6 & 64.2 & 13.1 \\
\hline & Kemisse & 310.0 & 866.0 & 594.1 & 157.3 & 26.5 & 71.8 & 13.4 \\
\hline & Artuma & 273.0 & 852.0 & 546.0 & 132.8 & 24.3 & 68.7 & 13.5 \\
\hline & senbete & 185.4 & 1040.0 & 681.7 & 207.2 & 30.4 & 68.7 & 13.0 \\
\hline \multirow{4}{*}{$\frac{\infty}{\infty}$} & Bati & 35.0 & 472.0 & 184.6 & 108.4 & 58.7 & 24.5 & 15.1 \\
\hline & Kemisse & 35.0 & 419.0 & 164.9 & 105.8 & 64.2 & 19.9 & 15.3 \\
\hline & Artuma & 10.0 & 511.0 & 164.4 & 118.4 & 72.1 & 20.7 & 14.9 \\
\hline & Senbete & 48.0 & 611.0 & 216.6 & 129.5 & 59.8 & 21.8 & 13.9 \\
\hline
\end{tabular}

Where, SD is standard deviation, CV is coefficient of variation, CT is percent of of seasonal totals contribution for annul total rainfall and PCI is precipitating concentration index.

Belg season rainfall variability The contribution of belg season (FMAM) to the annual rainfall totals varied from $19.9 \%$ in Kemisse to $24.5 \%$ in Bati (Table 2). This indicated that the contribution of the seasonal belg rainfall to the annual total was less than half of the contribution of the kiremt season rainfall. This result also agreed with the findings of Muluneh (2015) and Bewket and Alemayehu (2016) who reported the same comparable result.

The mean seasonal belg rainfall totals ranged from $164.4 \mathrm{~mm}$ at Artuma to $216.6 \mathrm{~mm}$ at Senbete station of the Special Zone with CV ranged from $58.7 \%$ to $72.1 \%$, and the SD value ranged from $\pm 105.8 \mathrm{~mm}$ to \pm 129.5 $\mathrm{mm}$, respectively (table 2). This implies that the seasonal belg rainfall was characterized by high variability as the classification of Hare (1983). Similar result were it has been reported by Muluneh (2015) also reported $150.5 \mathrm{~mm}$ at Kobo and $271.8 \mathrm{~mm}$ at sirinka in NEA during 1992-2012. Likewise, high seasonal belg rainfall variability was reported by Bewket (2009), over the Amhara Region, and Bewket and Alemayehu (2016) over North Shewa for the time period of 1975-2003,1979-2008, and 1983-2013, respectively.

The PCI value of the belg seasons varied between 11 and 16 , that indicates the zone received small amount rainfall with moderate monthly rainfall distribution in the study period (Table 2). The small amount rainfall observed with less stability and high variability indicate that the rainfall was not dependable and easily predictable, and the season was unlikely to sustain agricultural crop production on rainfall during 1986-2015.

\subsection{SEASONAL RAINFALL ANOMALY}

Kiremt seasonal rainfall anomaly The kiremt rainfall anomaly showed that $43.3 \%$ of the 30 years occurrance of rainfall defict and $46.7 \%$ of 30 years indicated positive departure from the normal or occurrence of good rainfall during the study years (Figure 4A). Among the 13 dry years moderate to severe drought years were observed in 1987,1989 1990, 1991,1993 and 2015. Among 14 posative years 1988, 1998, 1999, 2000, 2007 and 2010 were moderate to extreme wettest years in kiremt season of the study period (1986-2015). Korecha (2013) has also found that, the years $1987,1991,1997$, and 2009 recorded negative anomaly and the years 1988, 2006 and 2007 recorded positive anomaly of kiremt rainfall over Ethiopia. This implies could be challenged that rain fed crop production in the Special Zone has been challenged by risk of dry years during the study period. In agreement with this, Bewket (2009), Ayalew et al. (2012) and Muluneh (2015) noticed that the rain fed agriculture was highly at risk in the NEA.

Belg seasonal rainfall anomaly The belg rainfall anomaly showed that $50 \%$ of the 30 years experienced negative departure from normal (rainfall defict) and $33.3 \%$ of the 30 years showed positive departure from normal (good rainfall) (Figure 4B). Among those 15 dry years moderate to severe drought years are observed 1994,1999, 2008, 2009 and 2013, and among the 10 wet years 1987,1993,1995 and1996 recorded moderate to extreme wettest years in belg season of the study period (1986-2015). This indicates that drought frequencies were high in belg season than the kiremt and the annual records. Comparable result were also reported by Muluneh (2015), where the years,1992, 1999,2000,2008 2009 and 2011 recorded below mean rain fall in NEA during 1992-2012. 
(A) Zonal Mean Kiremt RF Anomaly

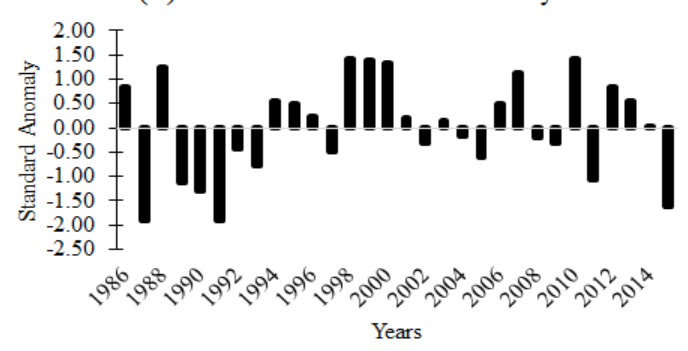

(B) Zonal Mean Belg RF Anomaly

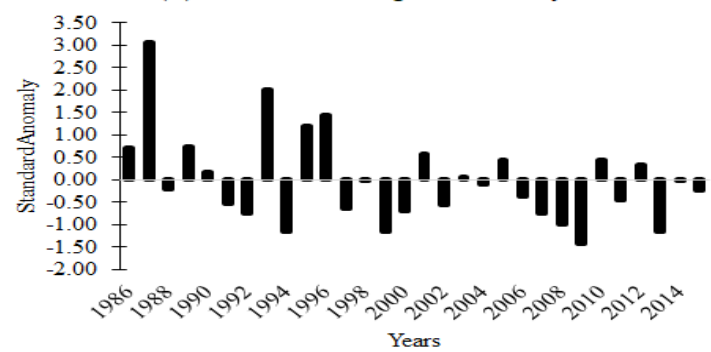

Figure 4. Areal mean annual and seasonal rainfall anomalies at OSZ, during 1986-2015

\subsection{RAINFALL TREND}

The Mann-Kendall trend test showed non-significantly increasing trends of kiremt rainfall at all stations while there was decreasing trend for belg total rainfall with statistically significant trends at Kemisse and Artuma (Table 3). In line with the result, Muluneh (2015) found that, increasing trend kiremt rainfall over the majority of the study area and the belg rainfall has shown a declining trend across the NEA during 1992-2012. Likewise, Hadgu et al. (2013) reported a icreasing kiremt rainfall trend at at Alamata and Edagahamus and decreasing trend in belg rainfall total at all study stations during the pariod1980-2009.

Table 3. Trend of past seasonal rainfall at OSZ, during 1986-2015.

\begin{tabular}{ccccc}
\multirow{2}{*}{ Stations } & \multicolumn{2}{c}{ Kiremt } & \multicolumn{2}{c}{ Belg } \\
\cline { 2 - 5 } & $\mathrm{Z}_{\mathrm{MK}}$ & Slop & $\mathrm{Z}_{\mathrm{MK}}$ & Slop \\
\hline Bati & $1.18^{\text {ns }}$ & 3.75 & $-0.82^{\text {ns }}$ & -2.40 \\
Kemisse & $0.25^{\text {ns }}$ & 1.19 & $-1.98^{\mathrm{c}}$ & -4.14 \\
Artuma & $0.62^{\text {ns }}$ & 1.67 & $-1.98^{\mathrm{c}}$ & -4.80 \\
Senbete & $1.86^{\text {ns }}$ & 9.15 & $-1.70^{\text {ns }}$ & -4.67
\end{tabular}

Where, Slope (Sen's slope) is the rate of change mm/year, ns is non-significant at all level of significance level and ${ }^{\mathbf{c}}$ is trend at 0.05 level of significance.

\subsection{RAINFALL CHARACTERIZATION}

\subsubsection{PAST START AND END OF SEASONS}

Start of belg season The belg season fulfilled the criteria of start of season in the past 30 years only for 14 years (46.7\%), $10(33.3 \%)$ years, $8(26.7 \%)$ years and $15(50 \%)$ years at Bati, Kemisse, Artuma and Senbete, respectively. Except at Senbete the median of the start of belg season disclose between March and May (Table 4). During 1986-2015, the belg mean started on DOY 141(May 20), 156 (Jun 4), 162 (Jun 10) and 138 (May17)at Bati, Kemisse, Artuma and Senbete, respectively experiencing high variability $(>30 \%)$ and low stability $(>50$ days). This indicated that, the start of belg season show low predictability of effective onset date/erratic and difficult to adopt fixed recommendations (date of sowing, cultivars, planting density, fertilizer rates and time of application) because of failure of start date of growing season across the study area. This shows that there was high risk of crop failure that is planting in belg season in the study area during 1986-2015.

Table 4. Past start date of belg season at OSZ, during 1986-2015

\begin{tabular}{|c|c|c|c|c|}
\hline \multirow{2}{*}{ Statistic } & \multicolumn{4}{|c|}{ Belg SOS } \\
\hline & Bati & Kemisse & Artuma & Senbete \\
\hline Early (DOY) & $62($ Mar 2) & 65 (Mar 5) & 65 (Mar 5) & 65 (Mar 5) \\
\hline $1^{\text {st }}$ Qrt (DOY) & 79 (Mar 19) & 98 (Apr 7) & 126 (May 5) & 85 (Mar 25) \\
\hline Median (DOY) & 179 (Jun 27) & $186(\mathrm{Jul} \mathrm{4})$ & 189(Jul 7) & 131(May 10) \\
\hline $3^{\text {rd }}$ Qrt (DOY) & 191(Jul 9) & 192 (Jul 10) & 193(Jul 11) & 192(Jul 10) \\
\hline Late (DOY) & 213(Jul 31) & 219(Aug 6) & 219 (Aug 6) & 221 (Aug 8) \\
\hline Mean (DOY) & 141(May 20) & 156 (Jun 4) & 162 (Jun 10) & 138 (May17) \\
\hline SD (DOY) & 56.6 & 51.8 & 51.1 & 56.1 \\
\hline $\mathrm{CV}(\%)$ & 40.2 & 33.1 & 31.5 & 40.7 \\
\hline
\end{tabular}

Start Kiremt Season Summary statistics for the past start of kiremt growing season during 1986-2015 in the OSZ is described in Figure 5. The median for onset of kiremt rainfall in the OSZ were 190 DOY (Jul 8) at Kemissse and Senbete, and 192 DOY (Jul 10) at Bati and Artuma. In line with the present result, Muluneh (2015) also presented the median SOS of kiremt growing season of 187 DOY (Jul-5), 190 DOY (Jul-8), 187 DOY (Jul-5) and 187 DOY (Jul-5) at Kombolcha, Kobo, Lalibela and Srinka, respectively with CV ranging from 4\% to 6\% during 1992-2012. Ayalew et al. (2012) has also found that 189 DOY (July-9) and 186 DOY (July-4) as the median SOS of the kiremt growing season at Srinka and Kombolcha, respectively, for the period 1978-2008. 

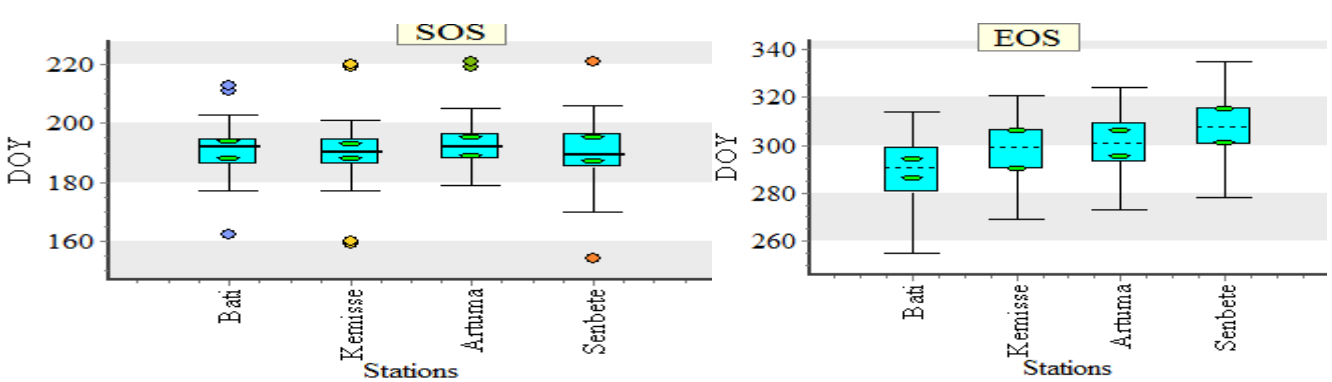

Figure 5. Box and whisker plots for start and end of Kiremt growing season at OSZ, during 1986-2015.

End of Kiremt Season This also showen in Figure 5, the Special Zone, the median end date of kiremt season (EOS) was on DOY 291 (Oct 17), 299 (Oct 25), 301 (Oct 27) and 307(Nov 2) at Bati, Kemisse, Artuma and Senbete, respectively with SD ranges from \pm 13 .1 days to \pm 14.5 days and CV ranges from $4.3 \%$ to $5 \%$ at Senbete and Bati, respectively. The main rainy season terminated during the last days of 280 DOY (Oct 6), 290 DOY (Oct 16), 293 DOY (Oct19) and 299 (Oct 25) once in four years' and terminated earlier than 300 DOY (Oct 26), 307 DOY (Nov 2), 309 DOY (Nov 4) and 315 DOY (Nov 10) at Bati and Senbete in three out of four years, respectively (Figure 5). Similar to this study, Ayalew et al. (2012) found that. the average ending date of kiremt rainfall ranged from DOY 266 (September 22) at Mehal Meda to DOY 304 (October 30) at Debark at ANRS.

\subsubsection{LENGTH OF SEASONS AND NUMBER OF RAINY DAYS}

A further note could also be made from Table 5 that rainfall season duration was dependent mainly on the onset date in the northern part of the zone (at Bati), rainfall duration was lower than 88 days in only $25 \%$ of the years, while it was lower than 111 days in $75 \%$ of the years. Similarly, the lower quartile for rainfall duration in the southern part of the special zone (at Senbete) was below 102 days in $25 \%$ and below 128 days for $75 \%$ of the study years; while in the central part of the zone the lower and upper quartiles were 99 and 121 at Kemisse and 96 and 116 at Artuma, respectively.

Table 5. Past length of growing period and number of rainy days in kiremt growing season at OSZ, during 19862015 .

\begin{tabular}{ccccc|cccc}
\hline \multirow{2}{*}{ Statistic } & \multicolumn{5}{l|}{ Length of Growing Period } & \multicolumn{3}{c}{ Number of Rainy Day } \\
\cline { 2 - 8 } & Bati & Kemisse & Artuma & Senbete & Bati & Kemisse & Artuma & Senbete \\
\hline Short (days) & 58 & 76 & 76 & 57 & 29 & 21 & 23 & 10 \\
$1^{\text {st }}$ Qrt (days) & 83 & 99 & 96 & 102 & 39 & 45 & 40 & 45 \\
Median (days) & 101 & 107 & 107 & 119 & 45 & 50 & 43 & 51 \\
$3^{\text {rd }}$ Qrt (days) & 111 & 121 & 116 & 128 & 48 & 56 & 49 & 57 \\
Long (days) & 129 & 133 & 139 & 146 & 61 & 73 & 75 & 71 \\
Mean (days) & 98 & 108 & 106 & 115 & 43 & 50 & 45 & 50 \\
SD (days) & 17.5 & 15.6 & 14.8 & 18.4 & 7.2 & 10.3 & 9.7 & 11.8 \\
CV (\%) & 17.8 & 14.4 & 13.9 & 16.0 & 16.8 & 20.8 & 21.6 & 23.5 \\
\hline
\end{tabular}

The variability of LGP ranged from $13.9 \%$ at Artuma to 17.8 at Bati (Table 5). This clearly showed that the central and southern part of the special zone have stable and longer length of growing period than the north part of the zone. Similar to this study, Ayalew et al. (2012) reported that Sirinka, Mahil Meda and Kombolcha experienced the least duration $(<100$ days) of kiremt rainfall, where as, Motta, Bahir Dar, Debark and Debre Markos experienced long duration ( $>140$ days) of kiremt rainfall.

Similar to LGP, number of rainy days (NRD) between start and end of seasons (Table 5), indicated that at Bati the number of rainy days less than 39 days in only $25 \%$ of the years, while it was lower than 48 days in $75 \%$ of the years with midian of 45 days.

This showed that NRD increased from north to south, but the variability was reversed across the special zone.

\subsubsection{PROBABILITY OF DRY SPELL}

The risk of getting 5,7,10 and 15 days of dry spells based on the fitted first order Markov chain probability values at OSZ during 1986-2015 is depicted in Figure 6. In belg season the probability of dry spell occurrence of 10 days' length was $60 \%$ at Bati, Kemisse, and Senbete and $70 \%$ at Artuma during the peak rainfall months (March and April) in belg season only between 88 DOY (March 28) and 118 DOY (April 27), respectively. Means that, the risk of dry spell occurrence of 5,7 and 10 days are greater than $60 \%$ during the belg season. On the other hand, the observed probability of dry spell occurrence greater than 15 days' length was less than $60 \%$ at Bati, Kemisse and senbete between 85 DOY (mar 25) and 121 DOY (April 30) and less than 50\% at Artuma between 82 DOY (Mar 22) and 130 DOY (May 9). 

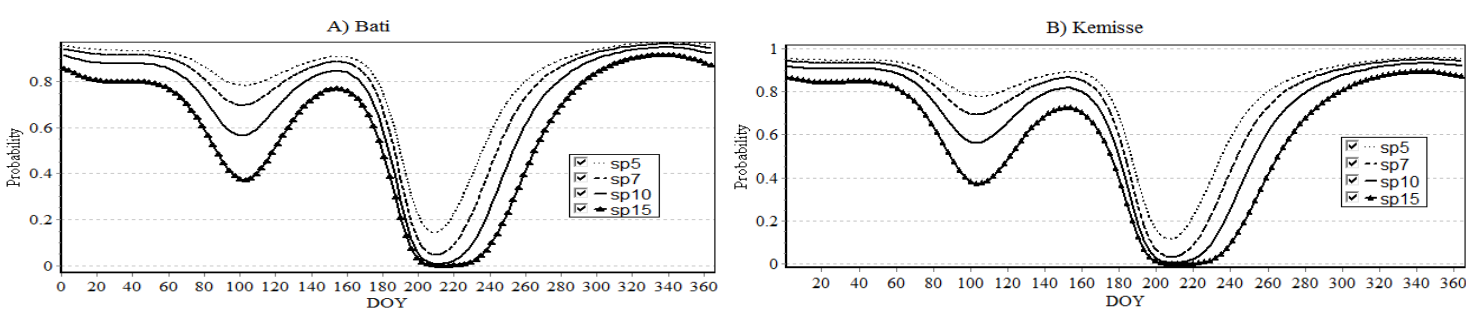
C) Artuma
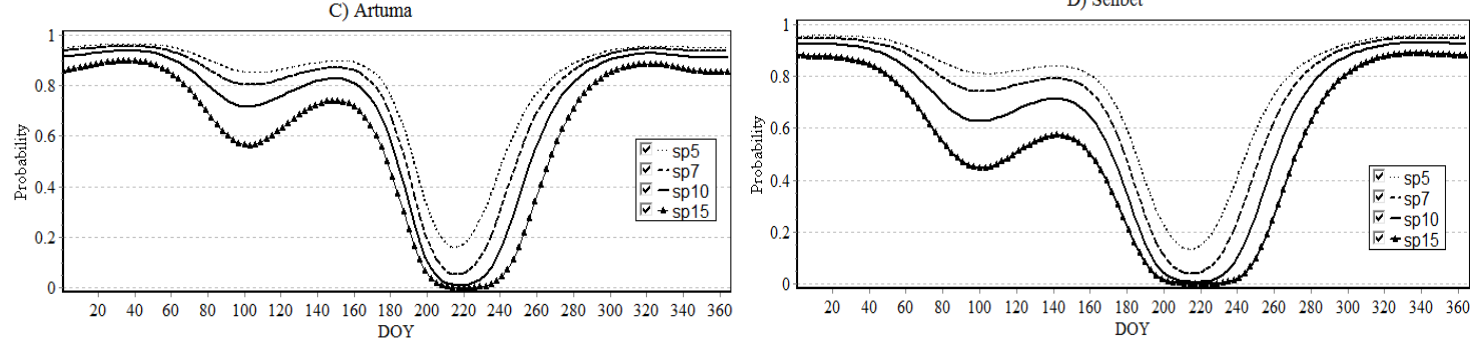

Figure 6. Probabilities of maximum dry spells exceeding 5, 7, 10 and 15 days' length in the OSZ, during 19862015

In kiremt season, the dry spell risk of being greater than 10 day consecutive dry spells was less than $50 \%$, and it is expected to occur at Bati from 184 DOY (July 2) to 256 DOY (Sep 12), at Kemisse 178 DOY (June 26) to 253 DOY (Sept 9), at Artuma 184 DOY(July 2) to 259 DOY (Sep 15), and at Senbete 169 DOY (June17) to 262 DOY (Sept 18) (Figure 4). This information is very important to farmers in the study area to decide on crop types to be cultivated and on planning sowing dates as a function of observed from the onset dates. In rain-fed farming, the intermittent dry spell becomes critical, particularly for the seedling establishment during the first 30 days or so after planting. Also used in decision making with respect to selecting dry spell resistance crop and field operations within the farming system.

\subsection{TEMPERATURE VARIABILITY AND TREND}

3.6.1 SPATIAL VARIABILITY TEMPERATURE

Maximum temperature (Tmax) The special zone experienced in kiremt season temperature of $29.3{ }^{\circ} \mathrm{C}$ to 33.1 ${ }^{0} \mathrm{C}$, and in belg season temperature of $28.4{ }^{\circ} \mathrm{C}$ to $31.6{ }^{\circ} \mathrm{C}$ (Figure 7). As is apparent from figure 7 , the special zone has experienced warmer in kiemt season than the belg season. The special zone with mean Tmax $28.3{ }^{\circ} \mathrm{C}$ at Bati, $31.5{ }^{\circ} \mathrm{C}$ at Kemisse and Artum and $29.8{ }^{\circ} \mathrm{C}$ at senbete. This shows that the central part is warmer than the north and southern part of the Special Zone.
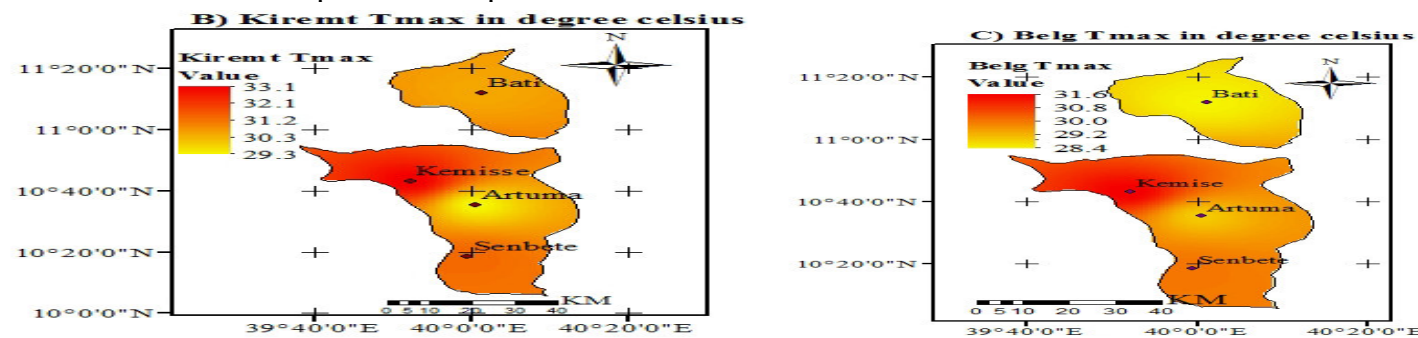

Figure 7. Spatial variability of mean annual and seasonal maximum temperature at OSZ, during 1986-2015

Minimum Temperature (Tmin) In the study area the of kiremt season Tmin was from $15.1{ }^{\circ} \mathrm{C}$ to $17.8^{\circ} \mathrm{C}$, and the belg season temerature varied from $14.3{ }^{\circ} \mathrm{C}$ to $16.0^{\circ} \mathrm{C}$ (Figure 8). Among the district in the study Zone, Bati district was colder interms of belg season Tmin, while during the kiremt season Artuma district colder over other districtes
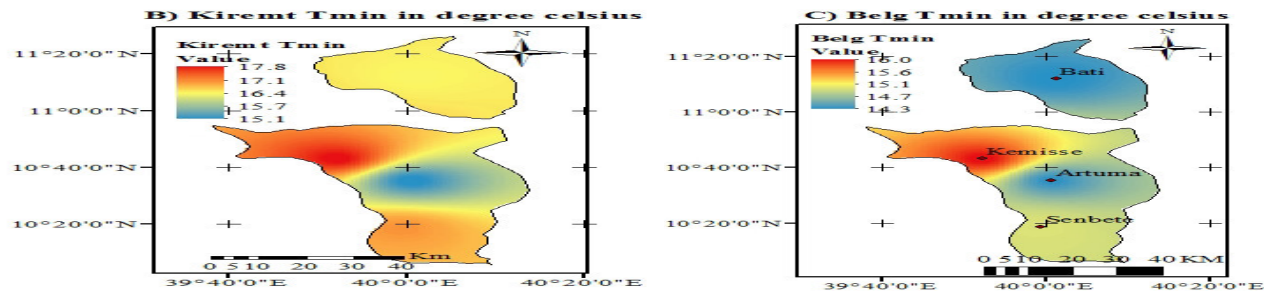

Figure 8. Spatial variability of mean annual and seasonal minimum temperature at OSZ, during 1986-2015 3.6.2 SEASONAL TEMPERATURE TREND

Kiremt season temperature trend The kiremt Tmax showed increasing trend at all stations studied in with statistically significant trend at Bati, Kemisse and Artuma stations. The Kiremt Tmax increment varied from 
$0.09{ }^{0} \mathrm{C}$ per decade in the central part of the zone to $0.40{ }^{0} \mathrm{C}$ per decade in north part of the special zone. Observed Tmin of kiremt also showed positive trend but the trende were non- significant (Table 6).

Table 6. Trend of mean annual and seasonal maximum and minimum temperature at OSZ, during 1986-2015

\begin{tabular}{|c|c|c|c|c|c|}
\hline \multirow{2}{*}{\multicolumn{2}{|c|}{ Districts }} & \multicolumn{2}{|c|}{ Kiremt } & \multicolumn{2}{|c|}{ Belg } \\
\hline & & $\mathrm{Z}_{\mathrm{MK}}$ & Slope & $\mathrm{Z}_{\mathrm{MK}}$ & Slope \\
\hline \multirow{4}{*}{ 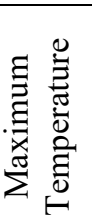 } & Bati & $2.32^{\mathrm{c}}$ & 0.040 & $4.07^{\mathrm{a}}$ & 0.082 \\
\hline & Kemisse & $2.57^{\mathrm{c}}$ & 0.038 & $4.60^{\mathrm{a}}$ & 0.082 \\
\hline & Artuma & $2.18^{\mathrm{c}}$ & 0.009 & $3.28^{\mathrm{b}}$ & 0.018 \\
\hline & Senbete & $1.75^{\mathrm{ns}}$ & 0.023 & $4.21^{\mathrm{a}}$ & 0.070 \\
\hline \multirow{4}{*}{ 㤩莺 } & Bati & $0.54^{\mathrm{ns}}$ & 0.007 & $-2.28^{c}$ & -0.045 \\
\hline & Kamisse & $1.78^{\mathrm{ns}}$ & 0.019 & $-0.25^{\mathrm{ns}}$ & -0.003 \\
\hline & Artuma & $0.96^{\mathrm{ns}}$ & 0.006 & $-1.39^{\mathrm{ns}}$ & -0.007 \\
\hline & Senbete & $1.43^{\mathrm{ns}}$ & 0.017 & $-0.68^{\text {ns }}$ & -0.007 \\
\hline
\end{tabular}

Where, $Z_{M K}$ is Mann-Kendall test statistic, Slope (Sen's slope) is the rate of change (Degree Celsius) per year; a is 0.001 level of probability; $\mathbf{b}$ is 0.01 level of probability; $\mathbf{c}$ is 0.05 level of probability. and ns is nonprobability at 0.05 probability level.

Belg season temperature trend The belg Tmax showed increasing trend at all statoins studied years in the zone with statistically significant. The increment varied from $0.18{ }^{0} \mathrm{C}$ per decade to $0.82{ }^{0} \mathrm{C}$ per decade. Conversely, the Tmin of belg showed negative trend at all studied stations of the special zone but nonsignificant except in the north part of the special zone (Table 6).

\section{CONCLUSIONS}

This study was undertaken to analyze the characteristics of historical girded climate data in OSZ of ANRS. Analysis of climate characteristics for the study area 1986-2015 for past. The area received mean total rainfall in kiremt season varied from $484.1 \mathrm{~mm}$ to $681.7 \mathrm{~mm}$ and in belg season it received varied from $164.4 \mathrm{~mm}$ to $216.6 \mathrm{~mm}$, respectively during 1986-2015. The past three decades seasonal rainfall trend test showed increasing in kiremt rainfall while decreasing in belg rainfall at all studied station of the special zone for that past. Regarding temperature analyses, except belg minimum temperature increasing trends in the study area during the study period.

During 1986-2015, the belg mean start of season 141 DOY (May 20), 156 DOY (Jun 4), 162 DOY (Jun 10) and 138 DOY (May17) at Bati, Kemisse, Artuma and Senbete, respectively with experienced high variability (>30\%) and low stability (>50 days). The median of kiremt season onsets are190 DOY (Jul 8) at Kemissse and Senbete and 192 DOY (Jul 10) at Bati and Artuma with CV ranges $4.8 \%$ at Artuma and 7.0\% at Senbete and SD ranges from \pm 9.3 days at Artuma and \pm 13.3 days at Senbete, respectivily. The variability of LGP ranges from $13.9 \%$ at Artuma to $17.8 \%$ at Bati and NRD ranges from $16.8 \%$ at Bati to $23.5 \%$ at Senbete of the Special Zone.

The occurrence of dry spell probability 5,7 and 10 days are greater than $60 \%$ during the belg season and in kiremt season, the dry spell risk of being 10 Day consecutive dry less than 50\% be fallen at Bati from 184 DOY (July 2) to 256 DOY (Sep 12), at Kemisse 178 DOY (June 26) to 253 DOY (Sept 9), at Artuma 184 DOY to 259 DOY (Sep 15), and at Senbete 169 DOY (June17) to 262 DOY (Sept 18). This information is very important to the farmers to decide on crop types to be cultivated and on planning sowing dates as a function of observed from the onset dates. Also used decision making with respect to selecting dry spell resistance crop and field operations within the farming system.

\section{REFERENCE}

Agnew, C.T. and A. Chappel. 1999. Drought in the sahel. GeoJournal 48: 299-311. agrometeorological indices. Journal of Agro Meteorology (I): $111-114$.

Ayalew Dereje, Kindie Tesfaye, Girma Mamo, Birru Yitaferu and Wondimu Bayu. 2012. Variability of rainfall and its current trend in Amhara Region, Ethiopia. African Journal of Agricultural Research,7(10):14751486.

Beck, C., Grieser, J., Rudolf, B., 2005. A new monthly precipitation climatology for the global land areas for the period 1951 to 2000. German Weather Service, Climate status report 2004, pp. 181-190.

Bewket Weldeamlak. 2009. Rainfall variability and crop production in Ethiopia; Case study in the Amhara region; proceeding of the $16^{\text {th }}$ International Conference of Ethiopian Studies, Addis Ababa, Ethiopia.

Bewket Woldeamlak and Alemayehu Arragaw. 2016. Local climate variability and crop production in highlands 
of Ethiopia . Environmental Development, 19: 36 - 48. http://dx.doi.org/10.1016/j.envdev.2016.06.002

Godswill, M., Dawit, K. and Dejene, A. 2007. A comparative analysis of rain fed and irrigated agricultural production in Ethiopia. Journal of Irrigation and Drainage. Vol 21 No 1. Springer Netherland.

Hadgu Gebre, Tesfaye Kindie and Mamo Girma. 2014. Analysis of climate change in Northern Ethiopia: implications for agricultural production. Theoretical and Applied Climatology ISSN 0177798X.Vol.117: P 3-17.

Hadgu Gebre, Tesfaye Kindie, Mamo Girma and Kassa Belay. 2013. Trend and variability of rainfall in Tigray, Northern Ethiopia: Analysis of meteorological data and farmers' perception. Academically Journal Environmental Science, 1(8): 159-171.

Hagos, F., Makombe, G., Namara, R.E. and Awulachew, S.B. 2009. Importance of irrigated agriculture to the Ethiopian economy: Capturing the direct net benefits of irrigation. Colombo, Sri Lanka: Int. Water Manage. Inst. p.37.

Hare, F.K. 1983. Climate and desertification. Revised analysis (WMO-UNDP) WCP-44: 5-20. Geneva, Switzerland.

Korecha, D. 2013. Characterizing the predictability of seasonal climate in Ethiopia. Doctoral dissertation in meteorology. University of Bergen, Norway.

Mandal, K.G., Kumar, A., Ghosh, S., Kundu, D.K., Panda, R.K., Mohanty, R.K., Raychaudhuri, M., Padhi, J., Majihi, P. and Sahoo, D.K. 2013. Analysis of rainfall and soil characteristics of kuanria canal command for water resource management research bulletin.

Mavi, H.S. and Tupper, G.J. 2004. Agro meteorology: principles and applications of climate studies in agriculture. Food Products Press ${ }^{\circledR}$, an imprint of the Haworth Press, Inc., 13: 904-1580.

Mesay Abebe. 2006. The onset, cessation and dry spells of the small Rainy Season (belg) of Ethiopia. National Meteorological Agency of Ethiopia, Addis Ababa. 10-13P.

Muluneh Getahune. 2015. Analysis of past and future intra-seasonal rainfall variability and its implications for crop production in the North Eastern Amhara Region, MSc. Thesis Haramaya University, Haramaya, Ethiopia.

NMA (National Meteorology Agency). 2007. Climate change national adaptation programme of action (NAPA) of Ethiopia: technical report, National Meteorological Agency, Addis Abeba, pp. 85

NMSA (National Meteorology Service Agency). 2001. Initial national communication of Ethiopia to the united nations framework convention on climate change (UNFCCC), Addis Ababa, Ethiopia, pp. 113.

Oliver, J.E., 1980. Monthly precipitation distribution: a comparative index. The Professional Geographer, 32: 300-309.

Raman, C.R.V. (1974). Analysis of Commencement of Monsoon Rains over Maharashtra State for Agricultural Planning. Published Scientific Report No. 216. Poona, India: India Meteorological Department.

Robel, A. A., E. DeGiuli, C. Schoof, and E. Tziperman. 2013. Dynamics of ice stream temporal variability: Modes, scales, and hysteresis, J. Geophys. Res. Earth Surf., 118: 925-936.

Segele, Z. T. and P. J. Lamb. 2005. Characterization and variability of Kiremt rainy season over Ethiopia. Meteorology and Atmospheric Physics, 89(1): 153-180.

Stern, R., Rijks, D., Dale, I. and Knoch, J. 2006. Instat climatic guide. Statistical services center, Reading University, UK.

Stern, R.D. and Coe, R. 1982. The use of rainfall models in agricultural planning. Agric. Meteorol., $26: 35-50$.

Yemenu, F. and Chemeda, D. 2013. Dry and wet analysis of two rainy seasons for decision support in agricultural water management for crop production in central highlands of Ethiopia. Journal of Biological and Agricultural Health care, 3(11):1-6

Yenigun K, Gumus V, Bulut H (2008) Trends in stream flow of the Euphrates basin. Turkey. Proc Inst Civil Eng Water Manag 161: 189-198. doi:10.1680/wama.2008.161.4.189 